\title{
Apocrine hidrocystoma of the scalp: Case report
}

\section{Sara Dahhouki, Rhizlane Chaoui, Selma El Kadiri, Zakia Douhi, Sara Elloudi, Hanane Baybay, Fatima Zahra Mernissi}

\author{
Department of Dermatology, CHU Hassan II, Fez, Morocco
}

Corresponding author: Dr. Sara Dahhouki, E-mail: dahhoukisara@gmail.com

Sir,

Hidrocystomas are uncommon benign adnexal tumors that derived from eccrine or apocrine sweat glands [1]. We report a case of a localized apocrine hidrocystoma on the scalp.

A 28 year old man consulted for a lesion of the scalp, that was asymptomatic and gradually increasing in size evolving over 5 years.

Dermatological examination showed a nodule, $2 \mathrm{~cm}$ in diameter, on the right parietal region of scalp with soft consistency and slightly bluish surface.

An excision of the lesion, where a thick-walled cyst with a serous content was noted (Figs. 1 and 2), was performed. Histology objected a large unilocular cystic space within dermis, lined by double layer of epithelial cells: an outer layer of flattened vacuolated myoepithelial cells and an inner layer of tall columnar cells with eosinophilic cytoplasm and basally located, round and oval vesicular nuclei (Fig. 3).

Based on the clinical, per operative exploration and histological finding, the diagnosis of hidrocystoma was made.

Hidrocystomas are benign adnexal tumors. They mostly affect young adults. They are preferentially located in the cervico cephalic region [1]. The initial diagnosis is based on the clinic, which remains insufficient, wrongly making other differential diagnoses. Only histology can confirm the diagnosis and clarify their apocrine or eccrine nature [2].

Apocrine hidrocystomas are in the form of cystic spaces within dermis. They are bordered by a double layer

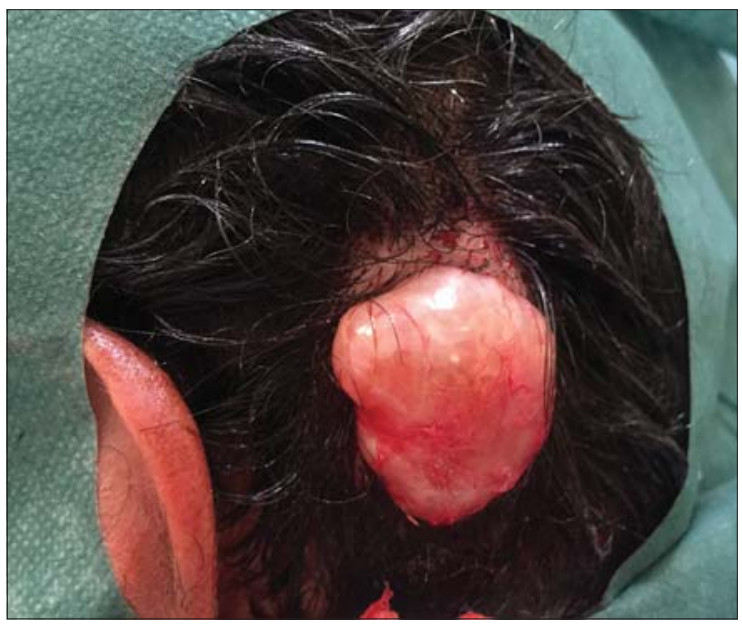

Figure 1: Cystic lesion of a hidrocystoma on the scalp.

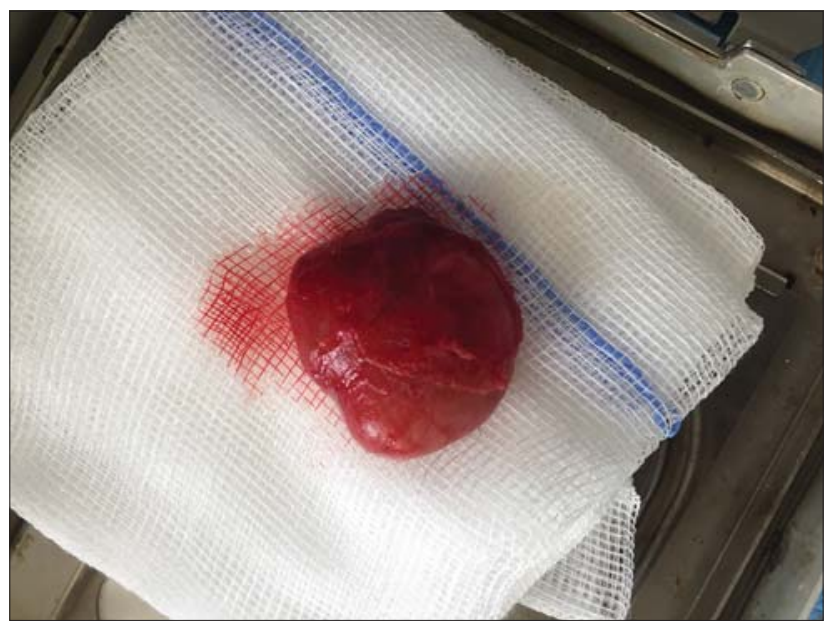

Figure 2: A cystic lesion after excision.

of epithelial cells, an outer layer composed of cubic myoepithelial cells which form intracavitary papillary digitations and an inner layer composed of secretory columnar cells with eosinophilic cytoplasm and a characteristic secretory apical decapitation protrusion $[1,2]$.

How to cite this article: Dahhouki S, Chaoui R, El Kadiri S, Douhi Z, Elloudi S, Bay Bay H, Mernissi FZ. Apocrine hidrocystoma of the scalp: Case report. Our Dermatol Online. 2020;11(e):e30.1-e30.2.

Submission: 22.02.2020; Acceptance: 05.03.2020

DOI: 10.7241 /ourd.2020e.30 


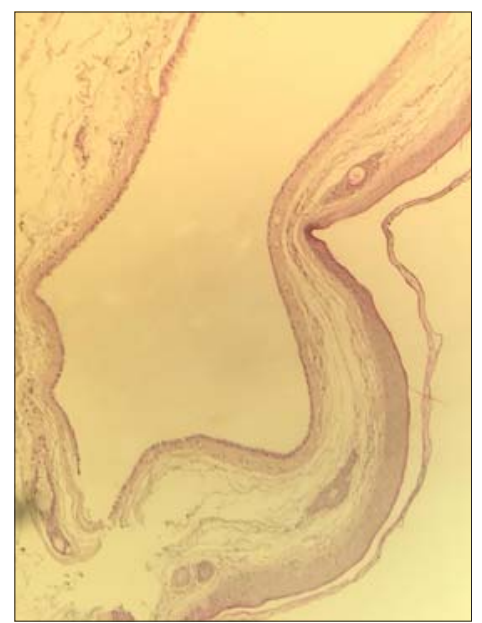

Figure 3: A large unilocular cystic space within dermis, lined by double layer of epithelial cells: an outer layer of flattened vacuolated myoepithelial cells and an inner layer of tall columnar cells with eosinophilic cytoplasm.

The treatment is essentially based on surgical excision [3].

\section{CONCLUSION}

Clinical diagnosis of hidrocystoma requires knowledge of differentiating characteristics in order to rule out other benign cystic lesions, and a biopsy must be obtained for histological study.

\section{Consent}

The examination of the patient was conducted according to the Declaration of Helsinki principles.

The authors certify that they have obtained all appropriate patient consent forms. In the form the patient(s) has/have given his/her/their consent for his/ her/their images and other clinical information to be reported in the journal. The patients understand that their names and initials will not be published and due efforts will be made to conceal their identity, but anonymity cannot be guaranteed.

\section{BIBLIOGRAPHY}

1. Yao JL, Phelps RG. Apocrine Hidrocystoma with proliferative features: Apocrine Cystadenoma. SM J Clin Pathol. 2017;2:1007.

2. Hafsi W; Badri T. Apocrine hidrocystoma. Stat Pearls Publishing, 2020 Jan-.

3. Poli PP, Creminelli L, Moramarco V, Del Gobbo A, Ferrante F, Maiorana C. Diagnostic workup and treatment of a rare apocrine hidrocystoma affecting the oral mucosa: a clinical and histological case report. Case Rep Dentist. 2017;2017:9382812.

Copyright by Sara Dahhouki, et al. This is an open-access article distributed under the terms of the Creative Commons Attribution License, which permits unrestricted use, distribution, and reproduction in any medium, provided the original author and source are credited.

Source of Support: Nil, Conflict of Interest: None declared. 